\title{
(息)
}

Citation:

Lawson, A (2020) Becoming Bourgeois: Benjamin Franklin's Account of the Self. English Literary History, 87 (2). pp. 463-489. ISSN 0013-8304

Link to Leeds Beckett Repository record:

https://eprints.leedsbeckett.ac.uk/id/eprint/6004/

Document Version:

Article (Accepted Version)

Copyright (C) 2020 Johns Hopkins University Press

The aim of the Leeds Beckett Repository is to provide open access to our research, as required by funder policies and permitted by publishers and copyright law.

The Leeds Beckett repository holds a wide range of publications, each of which has been checked for copyright and the relevant embargo period has been applied by the Research Services team.

We operate on a standard take-down policy. If you are the author or publisher of an output and you would like it removed from the repository, please contact us and we will investigate on a case-by-case basis.

Each thesis in the repository has been cleared where necessary by the author for third party copyright. If you would like a thesis to be removed from the repository or believe there is an issue with copyright, please contact us on openaccess@leedsbeckett.ac.uk and we will investigate on a case-by-case basis. 


\section{Becoming Bourgeois: Benjamin Franklin's Account of the Self}

In 1746 Benjamin Franklin had his portrait painted by the Boston artist Robert Feke (Figure 1). Franklin wears a light wig and a dark velvet coat, a ruffled silk shirt adding a hint of finery. He stands "erect and assured, his head cocked to one side, his right hand open to his side in a gesture that traditionally suggests the power to dispose of matters by a wave of the hand."1 Franklin was already a successful printer and bookseller, the owner of the Pennsylvania Gazette and the bestselling Poor Richard's Almanac. He was also the largest wholesale paper merchant in the colonies and official printer to the Pennsylvania assembly, as well as holding the post of Philadelphia postmaster. ${ }^{2}$ Two years after posing for his portrait Franklin signed an agreement with a former employee, David Hall, giving Hall the active management of his printing business for a term of eighteen years. ${ }^{3}$ Although he continued to work as postmaster and paper merchant Franklin had in effect retired from active business at the age of forty two with an annual income from the partnership of about $£ 620$ and an extensive portfolio of Philadelphia real estate ( $\underline{\mathrm{L}}, 3: 629 ; 599-603)$. Within another two years he had been elected as an alderman to the Philadelphia Corporation, a position that entitled him to sign his name "Benjamin Franklin, Esquire" (L, 3:166; 169). ${ }^{4}$ How did the youngest son of a struggling Boston tallow chandler, a man who "never inherited a shilling from any ancestor or relation," become a bourgeois gentleman $?^{5}$

[Insert Figure 1 here]

The power of the bourgeois lies in his ability to make promises and thereby enter, as Franklin did, into a variety of contractual relationships. In a well-known parable, Nietzsche describes what it took to "breed an animal with the prerogative to promise." making requires a degree of "control over the future," primitive, instinctual man has to abandon wanton impulse and the habit of forgetting his commitments (GM, 35). He must not only calculate the possible outcomes of any course of action but make himself "necessary, uniform, a peer among peers, orderly and consequently predictable" (GM, 36). He submits, first of all, to the "morality of custom," the "social straitjacket," and - since pain is the "most powerful aid to mnemonics" -- to long epochs of punishment in which "a few ideas" are made "ineradicable" ( $\underline{\mathrm{GM}}, 39)$. But the really transformative event occurs when one man borrows from another and promises to repay (GM, 40). The "feeling of guilt," of "personal obligation," 
originates in the "contractual relationship between creditor and debtor" and in the "very material concept" of debt (GM, 45, 40, 39). In order to become capable not just of making but of keeping promises, the individual "has to have a memory made for him," a "repository" of "hard, cruel, painful things" ( $\underline{\mathrm{GM}}, 40)$. He must "etch the duty and obligation of repayment into his conscience" (GM, 40). In Nietzsche's "prehistory," memory, calculation, and conscience are the products of a primordial disciplining of the self and a body braced for the consequences of delinquency or default (GM, 38). At the end of this process we find the sovereign individual, the "ripest fruit of the tree," a man with his "own independent, enduring will," a man whose "prerogative it is to promise" (GM, 37). In Feke's portrait Franklin stands before us as just such an individual, a "proud consciousness quivering in every muscle of what he has finally achieved and incorporated" (GM, 37).

In this essay I develop Nietzsche's argument biographically and historically by showing how Franklin's experience of debt and its financial and emotional management motivate the "actual labour of man on himself" we see performed in the Autobiography (GM, 36). Rather than offering up the homilies on wealth accumulation for which Franklin is well known, the Autobiography is concerned with the conduct of a particular form of life, an ethics adapted to the life of the colonial trader who must wrestle on a day-to-day basis with his financial obligations. ${ }^{7}$ David Waldstreicher has noted that Franklin's early writings reveal a familiarity with "accounts and balances" and "an increasingly savvy approach to costs and receipts." In his cultural history of financial accounting, Jacob Soll goes further by suggesting that bookkeeping was central to Franklin's vision of the world, an “organizing principle for his disparate interests" that helped the busy Philadelphia printer to order his "thoughts, writings, and moral well-being" as well as his finances. ${ }^{9}$ But Franklin scholars have not systematically evaluated the broader ethical significance of his accounting practices. I argue that Franklin's identification of the thirteen cardinal virtues and his methods for observing them were closely modelled on the methods of double-entry bookkeeping and that his moral system is the product of a financial crisis that threatened to destabilize his early career. In Franklin's moral-economic narrative assuming responsibility for one's debts and the accurate settling of accounts are the distinguishing marks of rational self-making, the foundation of a fully bourgeois conception of human flourishing.

\section{THE DEBT TO VERNON}


The key period in Franklin's formation as an economic subject began in 1723 when he ran away from Boston to Philadelphia and concluded in 1730 when he dissolved his first business partnership. In the Autobiography Franklin describes how he found employment in Philadelphia in Samuel Keimer's archaic printing house with its "old shatter'd Press" and "one small worn-out Fount" of type $(63 ; 30) .{ }^{10}$ Franklin got his first break when he came to the attention of Sir William Keith, lieutenant governor of Pennsylvania and Delaware, who was attempting to organize his own faction in the colony's assembly by publishing appeals for support from artisans and workingmen. ${ }^{11}$ Keith thought of Franklin as "a young Man of promising Parts" and offered him the contract for the colony's official business (31). "Sponsored" upward mobility beckoned. ${ }^{12}$ In the spring of 1724 Franklin returned to Boston and asked his father, Josiah Franklin, to fund the venture, but he had chosen a bad moment. In 1712 , Josiah had taken out a mortgage of $£ 250$ from the merchant Simeon Stoddard in order to buy his Union Street home; in order to repay Stoddard in 1723, he signed another mortgage agreement with Hannah Clark, borrowing $£ 220$ (L, 1: 34, 55). On May 1, 1724 Josiah was obliged to renew a note for a $£ 100$ from Josiah Hobbs, extending the repayment period for another year ( $\underline{\mathrm{L}}, 1: 251)$. Another debt to James Bowdoin for money borrowed in order to set up Franklin's older brother James as a printer was still outstanding (ㅌ, 1:55). With three creditors of his own to satisfy, Josiah offered the opinion that "Sir William's Proposition" was too risky and urged his son to follow a course of "steady Industry and prudent Parsimony" instead $(33 ; 34)$. In mid- or late May of 1724, Franklin set off, empty handed, for Philadelphia, sailing for New York via Newport, Rhode Island. What happened in Rhode Island played a shaping role in both Franklin's self-conception and his business practice.

Franklin called on his brother John and met "a Friend of his," the Rhode Island merchant Samuel Vernon, who was owed "about 35 Pounds Currency" by a customer in Pennsylvania (34). Vernon asked Franklin to collect the money and to keep it until he decided on how the sum should be sent to him. On arriving at New York Franklin came across an old school friend, John Collins, who planned to sail with him to Philadelphia. Ostensibly looking for a position in a counting house, Collins had been "drunk every day since his Arrival” (35). "He had gam'd too," Franklin recalls, "and lost his Money, so that I was oblig'd to discharge his Lodgings" (35). Franklin collected Vernon's money and used it to pay for his and Collins's passage. By treating money he had promised to safeguard as though it were a loan Franklin created a new chain of indebtedness. "[P]romising Repayment as soon as he should be in Business," Collins continued borrowing from Vernon's money to such an extent that Franklin became "distress'd" 
at the prospect of "being call'd on to remit it." (35). Collins then met a West Indies sea captain with "a Commission to procure a Tutor for the Sons of a Gentleman at Barbados" and left, promising to send Franklin "the first Money he should receive in order to discharge the Debt" (36). Franklin never heard from him again.

Using a printer's metaphor, Franklin concludes that "the Breaking into this Money of Vernon's was one of the first great Errata of my Life" (36). The affair seemed to prove that Josiah Franklin was not far off the mark in supposing his son "too Young to manage Business of Importance" (36). But Governor Keith was still interested in bestowing patronage on his young friend. Franklin embeds Keith's spoken words in his own text, as though they have lodged permanently in his memory:

[S]ince he will not set you up, says he, I will do it myself. Give me an Inventory of the Things necessary to be had from England, and I will send for them. You shall repay me when you are able (36).

The Governor then decided it would be better if Franklin were "on the Spot in England" to choose the types and to "make Acquaintances and establish Correspondences in the Bookselling, and Stationery Way" (36). Franklin was to sail on the London Hope, the annual mail packet, and purchase equipment to the value of $£ 100$ with a letter of credit to be provided by Keith “at a future time” $(36,40)$. On Christmas Eve, 1724, still “fretting” about Vernon's money and living in "daily Apprehensions" of being asked to return it, Franklin arrived in London to find that the Governor had failed to write the letter $(36 ; 37)$. A fellow passenger, the Quaker merchant Thomas Denham, laughed at the notion of a letter of credit from Keith, telling the disconsolate Franklin that he had "no Credit to give" (42). It was presumably from Denham that Franklin learned that it was Keith's "known Character" to be "liberal of Promises he never meant to keep" (36). Lacking a trained Nietzschean conscience, promise-making was simply "a Habit he had acquired" (42). Keith was a man who "wish'd to please everybody; and having little to give, he gave Expectations" (42).

The London sojourn quickly became a debacle, a series of failed, weak, or otherwise compromised promises, beginning with those made by Franklin himself. Before leaving Philadelphia, Franklin became engaged to marry Deborah Read on the understanding that, as a result of Keith's largesse, he would be "set up in my Business" on his return (38). But despite having "interchang'd some Promises" Franklin wrote Deborah a single letter, letting her know that he was "not likely soon to return" (43). Among the minor infractions recounted are those 
of Henry Pemberton, the physician and freethinker Franklin met at a coffeehouse, who promised -- "some time or other" -- to arrange a meeting with Sir Isaac Newton," an encounter that never happened (44). But the most serious betrayals of trust involve money and the incorrigible James Ralph, a Philadelphia friend with whom Franklin took lodgings. Franklin began his time in London with "15 Pistoles" to his name - Spanish gold coins with an equivalent sterling value of thirteen shillings (42). ${ }^{13}$ Although he immediately found work in a printing house his money was quickly "consumed" in making small loans to Ralph, as well as in "going to Plays and other Places of Amusement" (43). After eighteenth months Ralph owed Franklin "about 27 pounds," a "great Sum" out of his "small Earnings" (50). "Meanly employed" as a village schoolmaster, Ralph sought to improve his prospects by changing his name to "Benjamin Franklin," under which alias he began writing an epic poem (44). The friendship foundered when Franklin attempted "Familiarities" with Ralph's intimate friend, a Mrs. T., causing Ralph to cancel "all the obligations" he had been under to Franklin and telling him never to expect repayment (45). This is a comical but nightmarish world in which "strange new things" are constantly interposed between promise and performance, between the "original "I will"" and the "actual discharge of the will, its act" ( $\underline{\mathrm{GM}}, 36)$. We are in the realm of speculative fantasy where a man's word, his future, and even his identity appear to hang by a thread. The self is shaped like a promissory note.

Franklin's salvation lay in Thomas Denham, who had gone to England to buy goods for the store he intended to open in the Quaker City. One of the few things we know about Denham is that he was a reformed debtor. As a young merchant in Bristol, England, he had fallen into "bad Company" and "Spent his Substance."14 But around 1715 Denham emigrated to America and maintained such a "close Application to Business" that he acquired "a plentiful Fortune in a few Years" (48-49). Returning to England, he invited his creditors to a meal, placing under each plate "an Order on a Banker for the full Amount of the unpaid Remainder with Interest" (49). ${ }^{15}$ Denham now proposed to take on Franklin as a clerk in his Philadelphia store, employing him "to keep his Books (in which he would instruct me), copy his Letters, and attend the Store" (49). Franklin calculated that his earnings as a clerk would be lower than his wages as a compositor, but Denham's success story was so compelling that working for him represented "a better Prospect" (49). On the return voyage to Philadelphia in 1726 Franklin reflected on the "Giddiness and Inconstancy" of his early youth and decided that he needed a method of "regulating my future Conduct in Life" $(60 ; 50)$. He copied a "Plan of Conduct" into his journal, resolving to "form some scheme of action" in order to "live like a rational creature," 
a promise-keeper on a moral par with his new employer rather than hollow men like Ralph, Collins, and Keith (모 1:99-100).

The debt to Vernon was still gnawing at Franklin's conscience because the first resolution he made was "to be extremely frugal for some time," until he could repay the money he owed ( $\underline{\mathrm{P}}, 1: 100)$. He would apply himself "industriously" to the business in hand, and not "divert" his mind with "any foolish project of growing suddenly rich" ( $\underline{\mathrm{P}}, 1: 100)$. When Franklin began work in Denham's waterfront store he "attended the Business diligently, studied Accounts, and grew in a little Time expert at selling" (50). Franklin remembers how Denham counselled Franklin "as a Father, having a sincere Regard for me" as well as teaching him bookkeeping (50). Franklin, in turn, "respected and lov'd" his new mentor (50). But within a year Denham became gravely ill and Franklin was forced to return to Keimer's shop. He made the best of it, supervising the workmen, making ink, casting types, and acting as warehouse man. "Nothing now made me uneasy," he recalls, "but my Debt to Vernon, which I was yet unable to pay, being hitherto but a poor Economist. He however kindly made no Demand of it" (52). Vernon's forbearance gave Franklin the breathing space he needed to establish himself in business.

After yet another quarrel with Keimer, one of the workmen, Hugh Meredith, came to Franklin's lodgings and told him that Keimer was “in debt for all he possess'd, that his Creditors began to be uneasy, that he kept his Shop miserably, sold often without Profit for ready Money, and often trusted without keeping Account" (53). Certain that Keimer would fail, Meredith proposed a partnership. Franklin's "Skill in the Business" would be combined with capital supplied by Meredith's father, the profits to be shared equally (53). On June 1, 1728, Franklin and Meredith left Keimer and set up their own shop. In one of the Autobiography's most celebrated episodes, Franklin impressed his neighbors by working into the night on the printing of William Sewel's History of the of the Rise, Increase, and Progress, of the Christian People Called Quakers, "by far the biggest and most expensive book yet printed in Philadelphia." ${ }^{16}$ By September of 1729, Keimer was in such difficulty with his creditors that he was forced to sell his newspaper, the Pennsylvania Gazette to Franklin and Meredith for "a Trifle" (59). Franklin observes with relish that this asset, acquired from a crushed competitor, "prov'd in a few Years extremely profitable to me" (59).

Franklin's finances were, nonetheless, "shaky" (L, 1:377). "I was in debt for the Printing-House," he recalls, "I had a young Family coming on to be educated, and I had to contend with for Business two Printers who were establish'd in the Place before me" (76). The Philadelphia tradesman - like all those engaged in mercantile endeavours -- was walking a 
tightrope, trying to balance "the needs of his body, the problems of his business, and the longings of his soul." ${ }^{17}$ Leo Lemay detects evidence of the financial stresses Franklin was under in 1730 in his account with the merchant John Beard (L, 1:377). ${ }^{18}$ On July 4, Franklin purchased forty-six reams of paper from Beard for £27.12.0, paying £14. Four days later, on July 8 , he paid another $£ 6.12 .0$, but the next day he was able to pay only $£ 2$, leaving $£ 5$ outstanding. Franklin did a deal with Beard, giving him a promissory note for £4.10.0, and agreeing to pay the remaining 10 shillings to one of Beard's own creditors, a Mr Campion. $\mathrm{He}$ paid off the note on July 24 and met the obligation to Campion on September 5. Franklin had negotiated an extended period of grace, but his search for more time indicates the pressures he was under. His struggles to meet his expenses had intensified in the second week of July because, as he recalls, Vernon had written to him and "put me in mind of the Debt I ow'd him" (61). Vernon's letter was polite rather than threatening, allowing Franklin to make an "ingenuous" reply in which he acknowledged the debt and requested an extended period of grace (61). But still the problem remained.

Modern-day readers of the Autobiography frequently complain that it lacks psychological depth, containing "no intimations of neurotic behaviour, no dreams or nightmares, no crises of spirit, scarcely any inwardness." This is, apparently, the story of a man "in joyous harmony with himself," a man whose personal disclosures lack moments of "uncertainty, terror, or anxiety." 19 Mitchell Breitwieser puts this view most strongly by stating that there is an "absence of reformative turmoil" in the work. ${ }^{20}$ Franklin's smooth, equitable tone and the Augustan balance of his sentences certainly give the impression of an achieved moral equilibrium. But as we've seen, Franklin repeatedly mentions that the debt to Vernon troubled him. He begins the story with a prolepsis, mentioning that the debt was to later cause him "a good deal of Uneasiness" (34); in New York he was "distress'd to think" what he would do, if "call'd on to remit it" (35); in Philadelphia, he lived "in daily Apprehensions of being call'd upon by Vernon" (36-37); nothing made him "uneasy" except for "my Debt to Vernon" (52). As Lemay remarks, "[t]o judge by the number of times Franklin mentioned the debt," this erratum "bothered him more than any other" (느, 3:579). Franklin feels the morsus conscientiae, the "bite" or "gnawing pang" of conscience (GM, 55-56). But why should the debt to Vernon have caused him such perplexity?

The inner turmoil seems out of kilter with what we know about the early modern "economy of obligation." The American colonists, after all, relied on promises. Because British merchants insisted on payment in specie for imported goods there was a continual drain of silver and gold coins from the economy. ${ }^{21}$ The lack of a viable medium of exchange meant that 
everyone -- long-distance merchants, small traders, retailers, farmers, and artisans - owed money to someone and was, in turn, owed money by someone else. Debts piled up as oral promises to pay or as rolled-over entries in storekeepers' account books. ${ }^{22}$ These book debts were informal, non-interest-bearing loans extended over an indefinite period, implying a vague intention to pay rather than expressing such a promise explicitly. Borrowers would typically let an account run for seven months before paying, often in the form of commodity-money, with favoured goods such as beef, timber, and tobacco commonly accepted as a means of settling accounts. ${ }^{23}$ Within this framework of informal, neighbourly credit, historians assure us, "forbearance was the rule," meaning that "demands to pay or provide security" were perceived as "affronts to the debtor's honor or integrity." 24 If debt formed "the very fabric of sociability" then why, in 1730 , should a man's debts suddenly begin to matter? ${ }^{25}$

\section{MEN IN THEIR BARGAINS}

The answer lies in the history of the monetary policies pursued by the British authorities in response to the inflationary pressures unleashed by the Financial Revolution. The Bank of England's notes were first issued in 1694 with the backing of money lent to the government at a favourable rate of interest by landowners and manufacturers in the form of bank stock. ${ }^{26}$ The expansion of credit in the form of bank notes and tradable securities resulted in a period of currency inflation and "a fever of gambling on the stock market." 27 Since inflation helped debtors by reducing the real value of borrowed money over time, and harmed creditors, who received less than they had originally lent out, economic life became an intensified field of struggle between the groups. The essential conflict was between bullionists - landowners, manufacturers, and rentiers -- who saw money as a store of wealth that must be protected, and inflationists - merchants, traders, retailers, artisans and small farmers - who saw money as a medium of exchange that needed to be put into circulation. ${ }^{28}$

The Bank's creditors pressed for a "sound money" approach to the problem of the country's stock of clipped and hammered coins. They had the support of John Locke, who declared that "[m]en in their bargains" make contracts on the basis of "intrinsick value." Proposals for even a mildly inflationary recoinage were attacked by Locke on the grounds that "Landlord" and "Creditor" would be "defrauded of 20 per Cent. of what they contracted for." "29 In the Great Recoinage of 1696 , the price of gold was fixed at $£ 3.17 \mathrm{~s} .10^{1 / 2} \mathrm{~d}$ an ounce, "a definite quantity of bullion" which could not be altered. ${ }^{30}$ High denomination gold coins known 
as guineas began driving out silver shillings, whose value depreciated against them. By 1717 , when the government set its value at 21 shillings, the guinea had become the unit of account and Britain had effectively adopted the gold standard. ${ }^{31}$ The triumph of "the landed and the lending" was accompanied by the emergence of a new, moralizing discourse of debt. In Julian Hoppit's summary, "only those with probity and industry flowing in their veins could hope to command credit, be they governments, businessmen, farmers or consumers." 32

Attention shifted to the American colonies, whose monetary policy was now under the direct supervision of the Board of Trade. In 1690 Massachusetts had invented "the first paper money in the Western hemisphere." 33 Unable to pay its troops for an unsuccessful expedition against the French in Canada, the colony's legislature issued IOUs to its soldiers to be redeemed when they paid their taxes. Thereafter, bills of credit -- government-issued fiat money backed by tax receipts -- were accepted at par throughout the colonies. ${ }^{34}$ Although the adoption of paper money had the intended effect of increasing the scale and velocity of market exchanges, colonial legislatures simply couldn't print enough to keep up. As the volume of bills of credit increased their value depreciated against English sterling and Spanish dollars. ${ }^{35}$ The new currency also had consequences for credit conditions. Bills of credit were used both as ready cash and as a means of satisfying debt obligations. But with nervous investors selling British government stock and banks and calling in loans British merchants began to pressure their New England counterparts for payment. ${ }^{36}$ Rather than maintaining book debts merchants who traded with England were now using more formal, interest-bearing credit instruments such as promissory notes and bonds like the one signed by Josiah Franklin; they expected to be paid on time, with interest, and in cash. ${ }^{37}$ As the value of bills of credit fell "many debtors defaulted on their debts, knowing that, by the time a damage award was imposed against them, the debt would decrease in value. ${ }^{38}$ Creditors mounted a fight back against the wave of defaults.

The crunch year was 1730. The Pennsylvania legislature had already approved an Act for Taking Lands in Execution for the Payment of Debts, which removed traditional exemptions on real property from claims by creditors. ${ }^{39}$ On August 1, a new Pennsylvania statute required the full disclosure of a convicted debtor's assets and the assignment of his property to his creditors in return for his liberty. Petty debtors were required to work as indentured servants for their creditors for up to five years. ${ }^{40}$ The Board of Trade instructed Massachusetts to recall its existing bills of credit and restrict new issues. ${ }^{41}$ The wholly predictable result was "severe currency scarcity and tightened credit conditions as well as severe currency depreciation." 42 The drying up of the colonies' most prolific source of paper money together with the power and privilege exerted by British creditors made the repayment 
of local debts even less likely than before. Samuel Vernon was probably worried about holding Rhode Island bills, which were notorious for their tendency to depreciate since they were not backed by tax receipts and were issued in a disproportionately large volume in order to prime pump the colony's Caribbean and European trade. The prospect of being repaid in Pennsylvania silver no doubt prompted Vernon to write to Franklin, inquiring anxiously about his money. ${ }^{43}$

The most powerful disciplinary force regulating the economy was the debtor's own conscience. In order to realize their vision of New England as commercial bulwark against Catholicism, Puritan ministers had abandoned the traditional prohibition against usury. Once conceived as a commodity money was, according to Cotton Mather, "as Improvable a thing as any other;" there could therefore be no religious objection to lending it out at interest. ${ }^{44}$ But debts were regarded by colonial ministers and magistrates as "righteous" obligations. A man was in debt when he was "under Obligation to deliver up any Possessions unto another Man, upon the Demand thereof." 45 Failure to repay a debt was "a moral offense for which the debtor's conscience would suffer the penalty." ${ }^{46}$ Mather warned that "a Man in Debt, must have the Guilt of much Wrong lying upon him," guilt that "will bring a Cloud upon the Soul" and "arm the Conscience with Scourges grievously to last the Soul that shall be under it." Mather's Nietzschean lesson was that these mortifications were "worse than any of the ancient Punishments "inflicted by Creditors on their Debtors," such as the Roman Laws of the Twelve Tables that "allow'd, for the Creditors to tear the Debtors Limb from Limb." ${ }^{47}$ In Mather's account, the sense of obligation is lodged in the psyche of the debtor in visceral form:

The Debt is indeed, but as an Embryo, in its Formation, while the Time is not yet come or the Creditor to make his Demand. But it is more fully formed, and makes a very audible Cry, when a Man withholds from another Man, the Possessions, which ought Now to be delivered. $^{48}$

Franklin, in Philadelphia in 1730, heard the fully formed cry. A response was all the more urgent because, even as he sought Vernon's forbearance, Franklin was facing "another Difficulty" (61).

The merchant hired by Meredith's father to import the press and types was still owed half the charge for them, a sum of $£ 100$. Growing impatient, the merchant sued Simon Meredith for payment, threatening the partners' "hopeful Prospects" with ruin (61). Two of Franklin's wealthier friends, William Coleman and Robert Grace, offered to lend Franklin the money he 
needed, but they insisted that he separate from Meredith who was "often seen drunk in the Streets" (58; 62). On July 14, 1730, Franklin assumed responsibility for the debts of the partnership and repaid the $£ 100$ advanced by Meredith's father. Franklin's ledger entry for January 15, 1733 shows how he paid his debt to Simon Meredith in instalments as miscellaneous items over the preceding three years: two payments were made in cash, the rest made up in Osnaburg and Kersey (coarse fabrics used in making garments for workers and slaves), and a saddle. ${ }^{49}$ As soon as he was able to Franklin also settled his account with Vernon, paying the principal "with Interest \& many Thanks," meaning that the "Erratum" was "in some degree corrected" (61). The final redemption of the debt to Vernon and the dissolving of the partnership with Meredith had far-reaching consequences for Franklin's moral conception of himself. The debt to Vernon was more than a "momentary perturbation." It initiated a "critical reflection" by Franklin on his own nature. ${ }^{50}$

\section{BALANCING THE BOOKS}

Franklin's innovation was to elaborate the practices of bookkeeping he had learned from Denham into an ethics based on the concept of the balanced book. The concept first took hold in the northern Italy of the quattrocento when Venetian mercantile houses perfected the new accounting method of double entry bookkeeping, popularized by the Franciscan friar and mathematician Luca Pacioli. ${ }^{51}$ A merchant took an inventory of his stock, including cash and money owed to him, and kept three account books. In the first, the memoriale (also known as the cash book or waste book), he entered the details of his daily transactions. In the second, the giornale, or journal, he carefully transcribed each transaction, personifying it as either a debitore (debtor), for money, goods, or services received from a third party, or as a creditore (creditor), for payments or disbursements to a third party. The final account book was the quaderno, or ledger, which grouped transactions of the same kind or with the same person together and listed them alphabetically. The pages of the ledger were ruled into two columns. Pacioli specified that "[a]1l the creditors must appear in the Ledger at the right-hand side, and all the debtors at the left. All entries made in the Ledger have to be double entries - that is, if you make one creditor, you must make someone debtor." ${ }^{\circ 2}$ If a merchant bought cloth at a price of 240 ducats from another merchant, he would enter the cloth in the journal as $\underline{\operatorname{Dr}}$ (Debtor) 240, and the cash spent as $\underline{\mathrm{Cr}}$ (Creditor) for the same amount. In the ledger's cloth account, he would add the value of the cloth to the figure recorded in the inventory, and at the same time 
subtract the 240 ducats he had spent from the figure in the cash account. The accountant thus looked at the economy "as a circulation of debts and credits as well as a circulation of goods and money," rendering the reciprocity of exchange relations by entering every transaction twice. ${ }^{53}$ With the drawing of a distinction between left side (debt) and right side (credit), economic events were shaped and presented in a legible order: a book that could be read. ${ }^{54}$ The beauty of the system was that the merchant could understand his daily transactions "at a glance," finding "each thing in its place." 55

Pacioli's treatise was translated into English by John Mellis as A Briefe Instruction and Maner How to keepe Bookes of Accompts After the Order of Debitor and Creditor (1588), but the concept didn't catch on until the late seventeenth century when a series of "increasingly self-confident and detailed descriptions of the arts of commerce" appeared, a plethora of merchants' handbooks, bookkeeping primers, and economic treatises. ${ }^{56}$ These texts are tools for what Ceri Sullivan calls "the social production of a marketable self," a set of rhetorical strategies designed to promote the virtue of the trader, a man "expert, creditworthy, godly, and courageous."57 The merchant's fluctuating and hazardous world was to be secured by "demonstrable accuracy and painstaking labor over his accounting and writings, by discretion, commercial knowledge, and godly behaviour." 58 One of the most widely reprinted works popularizing the double-entry method was George Fisher's The Instructor: or Young Man's best Companion (1727), which the new partnership of Franklin and Hall republished in Philadelphia in 1748. Fisher instructed his mercantile reader "how to balance at the year's end, and thereby to know the state of your affairs and circumstances," emphasizing the assiduity and precision of the Italian method:

Even your Account of Cash. . . Call up all your Goods Bought, and those Sold, of what Kind soever, in each Account of Goods. ... Even all your Drs and all your Crs. in order as they lie. ... Even your Voyages, your Factors Accounts and Charges of Merchandize, or any other Accounts wherein is either Gain or Loss to the Account of Profit and Loss. ... Even your Stock. . . . Then Cast up the Dr. and Cr. Sides of your Balance; and if they come out both alike, then are your Accounts well kept. ${ }^{59}$

Get it wrong, and "you must find out your Error by pricking over your Books again," a process that involved "Examining every Article of the Journal against the Ledger and marking it."60 Early advocates of the double-entry system like Fisher forged a seemingly unbreakable link between "formal precision and moral rectitude or virtue." 61 
Double-entry bookkeeping formed a Foucauldian apparatus, a "heterogeneous ensemble" of moral, spiritual, ethical, and economic discourses with an especial prestige ${ }^{62}$ For Pacioli, the balance of the account book was an image of "the moral equilibrium of God," meaning that "[h] ard work, accounting, and profits were holy virtues." ${ }^{63}$ The accurate delineation of credits and debits in the ledger was virtue "made visible."64 Double-entry bookkeeping also "aroused affective outcomes," producing what Donna Merwick calls a sense of "gratification" that went beyond the simple notation of profit and loss. ${ }^{65}$ Fisher highlights "the Pleasure that accrues to a Person by seeing what he gains, by such species of Goods he deals in, and his whole Profit by a Year's Trade." The merchant, he writes, gains satisfaction from knowing "the true State of his Affairs and Circumstances; so that he may, according to his Discretion, retrench or enlarge his Expenses, \& c. as he shall think fit." ${ }^{66}$ Bookkeeping was recognized as a "vehicle for self-transformation," one that could "make you a better person." 67 It involved "considered dedication over time," a need to be "continually responsive to changeable and animate, or 'pulsatory,' rhythms."68 If there is something penitential in accounting practices -- "repetitious, time consuming, filled with self-scrutiny, driven by wide swings of emotion" - they also produce a kind of scrupulous pleasure that is peculiarly bourgeois, allowing the writer to control or regulate not just his business but himself. ${ }^{69}$

Accounting and self-examination formed part of a new "culture of watchfulness" that took hold among the Dissenting middle classes in the Atlantic world. ${ }^{70}$ Bookkeeping, with its scrupulous notations and balances, merged with nonconformist practices of spiritual autobiography and self-examination, the anxious search for signs of regenerating grace. Craig Muldrew notes the way in which ordinary people kept diaries in order to examine their moral behaviour and spiritual standing but also to record the payment of debts, the witnessing of loans, or the details of disputes over property and money with neighbours and family members. ${ }^{71}$ Christopher Gabbard highlights the way in which bookkeeping served as "one more means of achieving self-knowledge, of maintaining moral rectitude, and ultimately of taking stock of one's spiritual goods and evils." As a method of "personal self-reckoning," accounting assumed a "salvational dimension."72 As was the case with Mather's moral-spiritual treatise on debt, economic and religious precepts become merged in a single disciplinary apparatus. One of Franklin's favourite authors, Daniel Defoe, wrote on the subject of bookkeeping with "something approaching religious fervour.",73

Defoe began his career as a wholesale hosier in London, went bankrupt as a result of losses in the colonial tobacco and wine trades, and rebuilt his fortunes as a public accountant. ${ }^{74}$ In The Complete English tradesman (1727), Defoe proselytizes for the Italian method, 
providing specimen pages from a ledger. "If every thing is not carefully entred," the debtors' accounts "kept even, the cash constantly balanc'd, and the credits all stated," the tradesman is "like a ship at sea, steer'd without a helm; he is all in confusion, and knows not what he does." He can "give no account of himself to himself, much less to any body else."75 "A Tradesman's Books, like a Christian's Conscience," should "always be kept clean and clear; and he that is not careful of both will give but a sad account of himself to GOD or Man." given a fictional description of this process of moral accounting in The Life and Strange Surprizing Adventures of Robinson Crusoe (1719), in which his narrator writes as an advocate for accounting's affective outcomes.

Shipwrecked on his island, Crusoe attempts to understand his "Condition" and relieve the pressure of the thoughts "afflicting" his mind by drawing up the state of his affairs "in Writing." "77 Crusoe "set[s] the good against the Evil" by stating both "very impartially, like Debtor and Creditor, the Comforts I enjoy'd, against the Miseries I suffer'd." under Evil is "I am cast upon a horrible desolate Island, void of all hope of Recovery;" the corresponding entry under Good: "But I am alive, and not drown'd as all my Ship's Company was."79 Crusoe decides that, on striking a balance, there is more "on the Credit Side of the Accompt. $" 80$ This is a particularly mercantile kind of autobiographical writing, influenced as much by Pacioli as by Bunyan. But what's important about Crusoe's "bookkeeping conscience" is that it does not establish "an effective priority over his other thoughts and emotions," as Ian Watt argued. ${ }^{81}$ There is no "hypostasis of the economic motive," one that "logically entails a devaluation of other modes of thought, feeling, and action." 82 Crusoe's "tendency to rigorous moral and religious self-examination" is merged into the disciplinary techniques of accounting. ${ }^{83}$ Economic and spiritual motives have become inseparable and mutually reinforcing aspects of the ethic of watchfulness. In the 1730s, Franklin took this imbrication of accounting practice and self-scrutiny to a new level of precision and ambition.

\section{TAKING STOCK OF THE SELF}

Accounting is a practice that involves the taking of objects of various kinds (goods, services, money, assets, debts), and assigning them a place: debtor or creditor, capital or cash, profit or loss. The practice is designed to order and balance the relationships between the categorized objects so as to understand their relative value. But accounting, with its intensely visual ordering of the world into a kind of mathematical grid, also opens up the possibility for a system 
to become reflexive. The ethical lesson of accounting is not only that the self is always placed in a reciprocal relation to others, but also that it exists in a critical, monitoring relation to itself. The drawing of the distinction between debtor and creditor is an operation that allows the accountant to observe himself and to perform a recursive reading, going over the same ground in a way that clarifies the relations it discovers. ${ }^{84}$ It follows from the correcting of errors in accounts that the person who made the errors can be corrected, modified, and disciplined according, not to vague precepts, but to precise measurements. Accounting practice merges with autobiography to produce what critical accounting scholars Keith Hoskin and Richard Macve call "accountability," an "extended temporal state of constant liability." 85 Franklin's insight was that a reckoning could be performed for the virtues, treated as isolatable parts of the self. ${ }^{86}$

The project was first devised under the pressures of guilt over the debt to Vernon, the dissolving of the partnership with Meredith, and the new household responsibilities entailed by Franklin's marriage to Deborah Rogers. "It was about this time," Franklin writes, that "I conceiv'd the bold and arduous Project of arriving at moral Perfection. I wish'd to live without committing any Fault at anytime; I would conquer all that Natural Inclination, Custom, or Company might lead me into" (78). The first sign of the project's conception is the appearance in the Pennsylvania Gazette on 23 June 1730 of a "Dialogue between Philocles and Horatio." Horatio, acting as a spokesman for the hedonistic philosophy of Bernard Mandeville, attempts to justify the gratification of the passions by the mere fact that providence has allowed them to exist. Philocles replies:

That Man alone loves himself rightly, who procures the greatest possible Good to himself thro' the whole of his Existence; and so pursues Pleasure as not to give for it more than 'tis worth. ${ }^{87}$

Philocles describes the ideal self as an appraiser, "abstaining from the eloquent personality of impulse in order to treat impulses as quanta, costing so much, yielding so much, and thereby orienting itself to a temporally distant goal." 88 The ideas are drawn from Shaftesbury's Characteristics of Men (1711), a text in which the balanced self sought by classical philosophers and proponents of republican virtue is explicitly modelled on bookkeeping.

As a stoic and theist, Shaftesbury believed in a universe 'govern'd, order'd, or regulated for the best." 89 There was also an "Oeconomy of the Passions," which must be neither too strong nor too weak in order to "preserve a right BALANCE within." $" 90$ Since we are individual 
parts of a universal system or economy all we need to do in order to be virtuous is distinguish "good and natural" affections or passions from "ill and unnatural" ones. ${ }^{91}$ The nature of virtue consists in "a certain just Disposition, or proportionable Affection." 92 The bookkeeping metaphor lurking in Shaftesbury's argument surfaces in the conclusion to Shaftesbury's inquiry. The "main Sum or general Account" of our happiness is "either augmented or diminish'd" by the passions and affections we experience or accrue. It is not necessary for these passions to be provoked by particular objects in the world. But we should be able to add them up, to distinguish those that are pleasurable and tend to promote our happiness from those that are harmful and deleterious to it. As long as we have this ability, "our Ballance and Oeconomy hold good." "93 Franklin's own dialogue, "A Man of Sense" (1735) repeats the lesson. "The best Arithmetician may err in casting up a long Account; but having found that Error, he knows how to mend it," whereas the "habitually-vicious Man" cannot "correct his Faults in Accounting" ( $\underline{\mathrm{P}}, 2: 18)$. A "virtuoso moralist," Shaftesbury perfects "a kind of introspection" that, in Mary Poovey's summary, "'multiplies' the self by dividing it into segments that can act independently. $" 94$

What was good for the English landowner applied equally well to the colonial trader. ${ }^{95}$ Franklin divided himself up by making a list of thirteen cardinal virtues: temperance, silence, order, resolution, frugality, industry, sincerity, justice, moderation, cleanliness, tranquillity, chastity, and humility. Aiming for a "steady uniform Rectitude of Conduct" he began recording his transgressions of each of the virtues in "a little Book" $(79 ; 81)$ :

I allotted a Page for each of the Virtues. I rul'd each Page with red Ink, so as to have seven Columns, one for each Day of the Week, marking each Column with a Letter for the Day. I cross'd these Columns with thirteen red Lines, marking the Beginning of each Line with the first Letter of one of the Virtues, on which Line and in its proper Column I might mark by a little black Spot every Fault I found upon Examination, to have been committed respecting that Virtue upon that Day. (81)

In the manuscript of the Autobiography, Franklin drew a sample page for a week in which he wanted to focus on the virtue of temperance. As Franklin erased the spots or marks and reinscribed them for successive days, the little book became "full of Holes" (84). The problem provoked anxiety and with it, innovation: 
I transferr'd my Tables and Precepts to the Ivory Leaves of a Memorandum Book, on which the Lines were drawn with red Ink that made a durable Stain, and on those Lines I mark'd my Faults with a black Lead Pencil, which Marks I could easily wipe out with a wet Sponge. ... I always carried my little Book with me. (84)

Franklin advertised "Ivory-Leav'd Memorandum Books" for sale in his own shop: they were made up of thin leaves of ivory, held together like fans by a single pin. ${ }^{96}$ Accounting for the self becomes a mobile apparatus, the recording equipment of a process of continuous ethical monitoring that is seamlessly integrated into the fabric of everyday life. Refining and extending the methodical habits learned in Denham's store, Franklin follows a rigorous "Precept of Order," requiring that "every Part of my Business should have its allotted Time" (83). Franklin reserved a page in his little book for a "Scheme of Employment," a schedule for each working day (83). For Peter Stallybrass, Franklin's ivory memorandum book suggests "a new model for moral reformation." $" 97$ But the method was actually born in Renaissance Florence - it is Pacioli's mercantile ethic of watchfulness, updated for colonial Philadelphia. The ivory pages form the journal of the bourgeois soul. Nietzschean labor on the self is performed as accounting.

\section{AN ENDING OF ALL ACCOUNTS}

Franklin confronts his readers with a contradiction. As Alan Houston observes, “[p]erfection proved impossible," its pursuit "utterly exhausting and totally futile." 98 For Stallybrass, "the table of virtue is in fact a record of failures" - successive incidents of "intoxication, exuberant loquaciousness, eagerness, involvement, desire, lassitude and reverie, resentment and anger, comfort, intensity, and passion." 99 The record, as the moral faults were corrected, was supposed to become "progressively empty and finally blank, with no more faults to remember and record." ${ }^{100}$ But the ivory notebook, with its multiple erasures and corrections, revealed only an "interminable" process of "moral correction." 101 It was the animal that proved ineradicable in the man. Blessed, or cursed, with an almost perfect recall of his individual faults, Franklin eventually decided that he didn't have time to arrive at perfection:

My Scheme of ORDER, gave me the most Trouble, and I found, that tho' it might be practicable where a Man's Business was such as to leave him the Disposition of his Time, 
that of a Journeyman Printer for instance, it was not possible to be exactly observ'd by a Master, who must mix with the World, and often receive People of Business at their own Hours. (73)

The pursuit of moral perfection became a liability to the busy Philadelphia proprietor, employed in later life in "Voyages and Business abroad," a "Multiplicity of Affairs" that prevented a rigorous "Self-examination" (84).

Perhaps what really mattered was not an "internalized or autonomous self" but the "public perception of self in relation to a communicated set of both personal and household virtues." 102 Just as a bill of credit has no intrinsic value but is backed by a collective agreement to instil a token with monetary value, the self as a private stock of innate virtues is capable of mobilizing its moral assets only as long as it is seen to be acting virtuously. Striving to keep an immaculate set of accounts gained a trader credit, whether or not the numbers actually added up. Accounting networks such as those Franklin created with Simon Meredith and Samuel Vernon "created and sustained business operations, and enabled market players to lever resources at their disposal, especially their reliance on credit, reputation and trust." 103 It was Franklin's probity in accounting that led, in 1737, to his appointment as postmaster general for the Pennsylvania colony, replacing Bradford, whose "Negligence" and "Inexactitude" had displeased the Governor (95). Franklin's newspaper attracted more advertisers as a result of his appointment, and provided him with "a very considerable Income," a clear lesson "to those young Men who may be employ'd in managing Affairs for others that they should always render Accounts and make Remittances with great Clearness and Punctuality" (97).

It seems that once he had become successful Franklin's accounting standards slipped. The agreement made on Franklin's retirement was that Franklin would provide Hall with the firm's printing press, while Hall would run the business. The overhead costs - paper, ink, rent, bad debts and other expenses - would be equally shared by the partners. When the partnership was dissolved after its nineteen-year term, Franklin gave power of attorney to James Parker to examine the books and "make a final Ending of all Accounts"( $\underline{P}, 11: 422) .{ }^{104}$ In January, 1766, Parker submitted a report on the Franklin and Hall account, giving the totals to be debited to each partner and striking a final balance. The balance showed that Franklin owed Hall $£ 993$ $11 s .6 d(\underline{\mathrm{P}}, 13: 88)$. Alarmed, Franklin produced a series of detailed queries or "Observations," in which he disputed Parker's valuation of the printing presses, and queried the total income of the partnership, which Parker put at $£ 28,266$. This, to Franklin, seemed "very low." "Is there no Mistake?" he asked, "Is there not some great Omission" ( $\underline{P}, 13: 113)$. The largest debt 
Franklin owed to Parker were the first two items in the account, a charge of $£ 7,849$ for cash payments made by Hall to Franklin, and a charge of $£ 4,776$ for bills of exchange sent by Hall to England. During Franklin's prolonged stay in England, Hall had effectively been acting as Franklin's banker. Franklin asked whether some of Hall's receipts for money might have been paid already, and whether the real exchange rate should have been applied to the bills of exchange rather than an average. Finally, Franklin asked for what we would now call his intellectual property rights to be taken into account, claiming an uncredited "Copy Right" to Poor Richard's Almanac and to the Pennsylvania Gazette, and he claimed a right to half the debts still owed to the firm. In April 1767, he promised to send his observations to Hall but never did so. Hall died in 1772, before the former partners had settled the contentious details. Franklin's apparent failure to keep accurate accounts of his own led to a period of interminable wrangling in which virtue was far from being visible.

After Hall's death his sons inherited his share in the printing firm. The eldest son, William Hall, opened his account with Franklin by entering in the debit column the sum of $£ 993$ 11‥ 6‥ which Parker's report had shown that Franklin owed to his father ( $\underline{\mathrm{P}}, 13: 109)$. David Hall had reduced his claim against Franklin by agreeing to credit him with the Gazette and the uncollected debts (he did not agree to credit Franklin for the almanac). Even with these deductions, in January 1773 Franklin still owed David Hall’s estate the sum of $£ 459$ 6s. 21/4 $\underline{\mathrm{d}}$. According to Edward W. Labaree, "it appears that nothing was done to settle the account between Franklin and the Hall heirs during the twelve years that elapsed before Franklin returned to Philadelphia from France in 1785" (모 13:100). Franklin's attorney, James Parker, had died in 1770. The Hall sons were now disputing Franklin's rights to half the income from the Gazette, but Franklin waited until the fall of 1789 before he asked Parker's son-in-law, Gunning Bedford, to send him a copy of the original agreement with David Hall. Bedford sent the document to Franklin on November 29, 1789. Five months later, Franklin died, with a debt of almost $£ 460$ to the family of his former business partner still unresolved and unpaid, a sum equivalent, at today's values, to $£ 49,340 .{ }^{105}$ Up until his death, Franklin was still walking the tightrope, trying to balance the demands of his business and the needs of his soul, "propped up and weighed down," like today's neoliberal debtor, by the "cumulative weight" of his obligations. ${ }^{106}$ But by now, according to the adage that "whoever demands credit is a gentleman," he could afford to defer any final reckoning. ${ }^{107}$ The real power of the bourgeois lies in his ability to choose which promises he will keep. 


\section{NOTES}

1. Ormond Seavey, Becoming Benjamin Franklin: The "Autobiography and the Life (Univ. Park: Pennsylvania State Univ. Press, 1988), 165.

2. J. A. Leo Lemay, The Life of Benjamin Franklin, 3 vol. (Philadelphia: Univ. of Pennsylvania Press, 2006-09), 2: 377-401. Hereafter cited parenthetically by volume and page number and abbreviated $\underline{\mathrm{L}}$.

3. "Articles of Agreement with David Hall," The Papers of Benjamin Franklin, 42 vol., ed. Leonard W. Labaree and others (New Haven: Yale Univ. Press, 1961), 3:263-267. Hereafter parenthetically by volume and page number and abbreviated $\underline{\mathrm{P}}$.

4. On Franklin's path to gentility see Gordon S. Wood, The Americanization of Benjamin Franklin (New York: Penguin Press, 2004), 17-60. The practice of a bourgeois gentlemanly ideal in colonial America is discussed by Richard L. Bushman, The Refinement of America: Persons, Houses, Cities (New York: Knopf, 1992); C. Dallett Hemphill, "Manners and Class in the Revolutionary Era: A Transatlantic Comparison," William and Mary Quarterly 63.2 (2006): 345-372; David Shields, Civil Tongues and Polite Letters in British America (Chapel Hill: Univ. of North Carolina Press, 1997), 55-98; 175-208.

5. Benjamin Franklin, Will and Codicil, 17 July 1788, in The Papers of Benjamin Franklin, unpub. 1788-92, http://www.franklinpapers.org.

6. Friedrich Nietzsche, On the Genealogy of Morality, trans. Carole Diethe (Cambridge: Cambridge Univ. Press, 2007), 35. Hereafter cited parenthetically by page number and abbreviated GM. See also Mark Migotti, “"A Promise Made is a Debt Unpaid: Nietzsche on the Morality of Commitment and the Commitments of Morality," The Oxford Handbook of Nietzsche, eds. Ken Gemes and John Richardson (Oxford: Oxford Univ. Press, 2013), 509524. 
7. See Edward Cahill, "The English Origins of American Upward Mobility; or, the Invention of Benjamin Franklin,” ELH 83.2 (2016): 543-571; Sophus A, Reinert, “The Way to Wealth Around the World: Benjamin Franklin and the Globalization of American Capitalism," American Historical Review 120.1 (2015): 61-97. For classic accounts of Franklin as a representative of "bourgeois capitalism" see Max Weber, The Protestant Ethic and the Spirit of Capitalism, trans. Talcott Parsons (1930; rpt. London: Routledge, 2001), 13-38; Werner Sombart, The Quintessence of Capitalism (London: T. Fisher Unwin, 1915), 116-121.

8. David Waldstreicher, Runaway America: Benjamin Franklin, Slavery, and the American Revolution (New York: Hill \& Wang, 2004), 259n.30; 89.

9. Jacob Soll, The Reckoning: Financial Accountability and the Making and Breaking of Nations (London: Allen Lane, 2014), 152.

10. Benjamin Franklin, Benjamin Franklin's “Autobiography," ed. Joyce E. Chaplin (New York: W. W. Norton \& Company, 2012), 63; 30. Hereafter cited parenthetically.

11. See James N. Green, "English Books and Printing in the Age of Franklin,” $\underline{\text { A History of }}$ the Book in America, Vol. 1: The Colonial Book in the Atlantic World, eds. Hugh Amory and David D. Hall (Chapel Hill: Univ. of North Carolina Press, 2007), 249-250. See also Gary B. Nash, Quakers and Politics: Pennsylvania, 1681-1726 (Princeton: Princeton Univ. Press, 1968), 332-335; Frederick Barnes Tolles, James Logan and the Culture of Provincial America (Boston: Little Brown and Company, 1957), 113-114; 124-126.

12. Wood, Americanization of Benjamin Franklin, 26.

13. John J. McCusker, Money and Exchange in Europe and America, 1600-1775: A Handbook (Chapel Hill: Univ. of North Carolina Press, 1978), 7.

14. Bristol Friends Two-Weeks Meeting (1715), qtd. in Frederick B. Tolles, Meeting House and Counting House: The Quaker Merchants of Colonial Philadelphia, 1682-1763 (Chapel Hill: Univ. of North Carolina Press, 1948), 249n.4. 
15. On the reputation of Quaker businessmen for honesty and integrity see Tolles, Meeting House and Counting House, 45-62, 247-250. On the economic success of Philadelphia's Quaker merchants see Thomas M.Doerflinger, A Vigorous Spirit of Enterprise: Merchants and Economic Development in Revolutionary Philadelphia (Chapel Hill: Univ. of North Carolina Press, 1986), 59-61.

16. James N. Green and Peter Stallybrass, Benjamin Franklin: Writer and Printer (London: British Library, 2006), 28.

17. Anthony Grafton, Leon Battista Alberti: Master Builder of the Renaissance (Cambridge, MA: Harvard Univ. Press, 2002), 152.

18. The Accounts of Benjamin Franklin Through 1747, III. Accounts. 1730s, http://udspace.udel.edu/handle/19716/2354.

19. Herbert Leibowitz, Fabricating Lives: Explorations in American Autobiography (New York: New Directions, 1991), 29; 30.

20. Mitchell Breitwieser, Cotton Mather and Benjamin Franklin: The Price of Representative Personality (Cambridge: Cambridge Univ. Press, 1984), 228. For the argument that Franklin was sanguine about his personal debts see also Jennifer Baker, Securing the Commonwealth: Debt, Speculation, and Writing in the Making of Early America (Baltimore: Johns Hopkins Univ. Press, 2005), 85.

21. Bruce H. Mann, Republic of Debtors: Bankruptcy in the Age of American Independence (Cambridge, MA: Harvard Univ. Press, 2002), 18. See also McCusker, Money and Exchange, 116-117.

22. Mann, Republic of Debtors, 3.

23. W. T. Baxter, "Accounting in Colonial America," Studies in the History of Accounting, eds. A. C. Littleton and B. S. Yamey (London: Sweet and Maxwell, 1956), 274-275. For an analysis of informal, local exchanges see Michael Merrill, "'Cash is Good to Eat:' SelfSufficiency and Exchange in the Rural Economy of the United States," Radical History Review 
3 (1976): 52-61. On the prevalence of book debts see also W. T. Baxter, "Credit, Bills, and Bookkeeping in a Simple Economy," Accounting Review 21.2 (1946): 154-66; Claire Priest, "Currency Policies and Legal Development in Colonial New England," Yale Law Journal 110 (2001): 1328-1330; on Franklin's book debts see Alan Houston, Benjamin Franklin and the Politics of Improvement (New Haven: Yale Univ. Press, 2008), 46-47.

24. Mann, Republic of Debtors, 17. See also Bruce Mann, Neighbors and Strangers: Law and Community in Early Connecticut (Chapel Hill: Univ. of North Carolina Press, 1987), 11-27; David Thomas Konig, Law and Society in Puritan Massachusetts: Essex County, 1629-1692 (Chapel Hill: Univ. of North Carolina Press, 1979), 82-88.

25. David Graeber, Debt: The First 5000 Years, (Brooklyn: Melville House, 2012), 329. See also Craig Muldrew, The Economy of Obligation: The Culture of Credit and Social Obligations in Early Modern England, (Basingstoke: Macmillan, 1998), 98-103, 106-9; Craig Muldrew, "Hard Food for Midas: Cash and Its Social Value in Early Modern England," Past and Present 170 (2001): 78-120.

26. See P. G. H. Dickson, The Financial Revolution in England: A Study in the Development of Public Credit, 1688-1756 (London: Macmillan, 1967), 39-75.

27. Sir Albert Feaveryear, The Pound Sterling: A History of English Money (Oxford: Clarendon Press, 1963), 130.

28. The terms "bullionist" and "inflationist" did not come into use until the early nineteenth century, with the publication of Henry Thornton, An Inquiry into the Nature and Effects of the Paper Credit of Great Britain (1802). I use them in order to highlight the class divisions underlying fundamental questions of economic theory, and the need for a longer historical perspective on repeated clashes between creditor and debtor interests. See David Laidler, "The Bullionist Controversy,” The New Palgrave Dictionary of Economics, Vol. 1, eds. John Eatwell et al (London: Macmillan, 1987), 289-293; Frank W. Fetter, The Development of British Monetary Orthodoxy, 1797-1875 (Cambridge: Harvard Univ. Press, 1965), 26-63.

29. John Locke, Further Considerations Concerning Raising the Value of Money (1695), in Locke on Money, Vol. 2, ed. Patrick Hyde Kelly (Oxford: Clarendon Press, 1991), 415; 416. 
On Locke's monetary theories see Terrence Hutchinson, Before Adam Smith: The Emergence of Political Economy, 1662-1776 (Oxford: Basil Blackwell, 1988), 56-86.

30. Feaveryear, Pound Sterling, 148. On the recoinage debate see Joyce Appleby, Economic Thought and Ideology in Seventeenth-Century England (Princeton: Princeton Univ. Press, 1978), 199-241; Deborah Valenze, The Social Life of Money in the English Past (Cambridge: Cambridge Univ. Press, 2006), 39-43; Thomas J. Sargent and François R. Verde, The Big Problem of Small Change (Princeton: Princeton Univ. Press, 2002), 261-290; Carl Wennerlind, "Credit-Money as the Philosopher's Stone: Alchemy and the Coinage Problem in SeventeenthCentury England," History of Political Economy 35 (2003, suppl.): 235-262.

31. Feaveryear, Pound Sterling, 152; see also Sargent and Verde, Big Problem of Small Change, 291-305.

32. Julian Hoppit, “Attitudes to Credit in Britain, 1680-1790,” Historical Journal 33.2 (1990): 320.

33. Christine Desan, "The Market as a Matter of Money: Denaturalizing Economic Currency in American Constitutional History," Law and Social Inquiry 30.1 (2005): 15.

34. On the theory of fiat money see Desan, "The Market as a Matter of Money," 15-23. On monetary debates in provincial Massachusetts see Mark Valeri, "William Petty in Boston: Political Economy, Religion, and Money in Provincial New England,” Early American Studies 8.3 (2010): 561-565; Margaret Ellen Newell, From Dependency to Independence: Economic

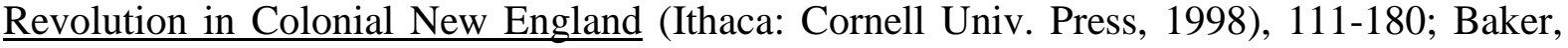
Securing the Commonwealth, 1-42. On Franklin's arguments for paper money see Houston, Benjamin Franklin and the Politics of Improvement, 41-46; on Franklin's printing of paper money for the colonies of Pennsylvania, Delaware, and New Jersey see Green and Stallybrass, Benjamin Franklin: Writer and Printer, 55; Benjamin H. Irvin, "Benjamin Franklin's 'Enriching Virtues,"” Common-place 6.3 (2006), http://www.common-place-archives.org/.

35. McCusker, Money and Exchange, 139-141. 
36. Priest, "Currency Policies," 1368; Julian Hoppit, "Financial Crises in Eighteenth-Century England," Economic History Review 39.1 (1986): 49.

37. Priest, "Currency Policies," 1351; see also Mann, Neighbors and Strangers, 171.

38. Priest, "Currency Policies," 1365.

39. Claire Priest, "Creating an American Property Law: Alienability and Its Limits in American History," Harvard Law Review 120.2 (2006): 412.

40. Peter J. Coleman, Debtors and Creditors in America: Insolvency, Imprisonment for Debt and Bankruptcy, 1607-1900 (Madison: State Historical Society of Wisconsin, 1974), 143.

41. Priest, "Currency Policies," 1369.

42. Priest, "Currency Policies," 1371.

43. See Newell, From Dependency to Independence, 198; McCusker, Money and Exchange, 180.

44. Cotton Mather, Thirty Important Cases (Boston, 1699), qtd. in Valeri, "William Petty in Boston," 550.

45. Cotton Mather, Fair Dealing Between Debtor and Creditor (Boston, 1716), 5, Eighteenth Century Collections Online, https://quod.lib.umich.edu/e/ecco/.

46. Mann, Republic of Debtors, 43.

47. Mather, Fair Dealing Between Debtor and Creditor, 24.

48. Mather, Fair Dealing, 6.

49. The Accounts of Benjamin Franklin Through 1747, III. Accounts. 1730s, http://udspace.udel.edu/handle/19716/2354; Roderick A. McDonald, The Economy and 
Material Culture of Slaves: Goods and Chattels on the Sugar Plantations of Jamaica and Louisiana (Baton Rouge: Louisiana State Univ. Press, 1993), 112, 154.

50. Breitwieser, Cotton Mather and Benjamin Franklin, 247.

51. On Pacoli's system, see Jane Gleeson-White, Double Entry: How the Merchants of Venice Created Modern Finance (New York: W. W. Norton, 2012), 91-114; Alfred W. Crosby, The Measure of Reality: Quantification and Western Society, 1250-1600 (Cambridge: Cambridge Univ. Press, 1998), 199-24; Jere Cohen, “Rational Capitalism in Renaissance Italy,” American Journal of Sociology 85.6 (1980): 1340-1355; Soll, The Reckoning, 48-55.

52. Luca Pacioli, The Rules of Double-Entry Bookkeeping, trans. John B. Geijsbeek (N.p.: IICPA Publications, 2010), 93.

53. Dirk Baecker, “The Writing of Accounting,” Stanford Literature Review 9.2 (1992): 164.

54. Baecker, "Writing of Accounting," 166.

55. Pacioli, Rules of Double-Entry Bookkeeping, 16; 17.

56. Ceri Sullivan, The Rhetoric of Credit: Merchants in Early Modern Writing (Madison: Farleigh Dickinson Univ. Press, 2002), 16.

57. Sullivan, Rhetoric of Credit, $11 ; 17$.

58. Sullivan, Rhetoric of Credit, 23.

59. George Fisher, The Instructor: or, Young Man's best Companion (London, 1737), 210, 211. Web. Ecco. Accessed 25 October 2014.

60. Fisher, The Instructor, 211.

61. Mary Poovey, A History of the Modern Fact: Problems of Knowledge in the Sciences of Wealth and Society (Chicago: Univ. of Chicago Press, 1998), 33. 
62. Michel Foucault, Power/Knowledge: Selected Interviews and Other Writings, 1972-1977, trans. Colin Gordon and others (New York: Pantheon Books, 1980), 194. See also Giorgio Agamben, What Is an Apparatus? And Other Essays, trans. David Kishik and Stefan Pedatella (Stanford: Stanford Univ. Press, 2009), 14.

63. Soll, Reckoning, 50-51; 51.

64. Poovey, History of the Modern Fact, 43.

65. Donna Merwick, "A Genre of Their Own: Kiliaen van Rensselaer as Guide to the Reading and Writing Practices of Early Modern Businessmen," William and Mary Quarterly 65.4 (2008): 671; 672 .

66. Fisher, The Instructor, 152.

67. Bruce G. Carruthers and Wendy Nelson Espeland, “Accounting for Rationality: DoubleEntry Bookkeeping and the Rhetoric of Economic Rationality," American Sociological Review 97.1 (1991): 41.

68. Merwick, "Genre of Their Own," 672.

69. Merwick, "Genre of Their Own,” 687.

70. Soll, Reckoning, 120. On the connections between "moral bookkeeping" and "business chronicling" see James Aho Confession and Bookkeeping: The Religious, Moral, and Rhetorical Roots of Modern Accounting (Albany: State Univ. of New York Press, 2005), 23, 40 .

71. Muldrew, Economy of Obligation, 64. See also Adam Smyth, Autobiography in Early Modern England (Cambridge: Cambridge Univ. Press, 2010), 57-121.

72. D. Christopher Gabbard, “The Dutch Wives' Good Husbandry: Defoe's Roxana and Financial Literacy,” Eighteenth-Century Studies 37.2 (2004): 240. 
73. Gabbard, "Defoe's Roxana and Financial Literacy," 239.

74. See Paula R. Backscheider, Daniel Defoe: His Life (Baltimore: Johns Hopkins Univ. Press, 1989), 30-114.

75. Daniel Defoe, The Complete English tradesman, in familiar letters: directing him in all the $\underline{\text { several Parts and Progressions of Trade (London, 1727), 14, Eighteenth Century Collections }}$ Online, https://quod.lib.umich.edu/e/ecco/.

76. Defoe, Complete English tradesman, 269.

77. Defoe, The Life and Strange Surprizing Adventures of Robinson Crusoe, of York, Mariner (London, 1719), 76. Eighteenth-Century Collections Online.

78. Defoe, Life and Strange Surprizing Adventures of Robinson Crusoe, 76.

79. Defoe, Life and Strange Surprizing Adventures of Robinson Crusoe, 76.

80. Defoe, Life and Strange Surprizing Adventures of Robinson Crusoe, 77.

81. Ian Watt, The Rise of the Novel: Studies in Defoe, Richardson, and Fielding (Harmondsworth: Penguin Books, 1972), 70.

82. Watt, Rise of the Novel, 71.

83. Watt, $\underline{\text { Rise of the Novel, } 84 .}$

84. Baecker, "Writing of Accounting," 159.

85. Keith W. Hoskin and Richard H. Macve, "Accounting and the Examination: A genealogy of Disciplinary Power," Accounting, Organizations and Society 11.2 (1986): 124n.8. 
86. Lemay dates the period of the project to which Franklin refers by a paper he drafted on May 9, 1731, headed “Observations on my Reading History in Library," later incorporated into the Autobiography (L, 2:39). Apparently inspired by the example of the Library Company, Franklin conceived the idea of a "united Party for Virtue," one that would incorporate "the Virtuous and good Men of all Nations" into "a regular Body, to be govern'd by suitable good and wise Rules." Such a party would counteract the universal tendency for each individual to act with only "his particular private Interest in View," thus losing sight of the common good and creating "all Confusion" (Papers 1: 192-193). In the Autobiography Franklin records his belief that each proposed member of the "Society of the Free and Easy" should have completed a "Thirteen Weeks Examination and Practice of the Virtues," as described in "the beforementioned Model” (90). The model must therefore have been in place by May of 1731 .

87. Anonymous, "Dialogue between Philocles and Horatio," qtd. in Breitwieser, Cotton Mather and Benjamin Franklin, 194. Franklin transcribed the dialogue from the London Journal; it was probably authored by a friend and correspondent of Lord Shaftesbury. See A. O. Aldridge, “Franklin's 'Shaftesburian Dialogues' Not Franklin's: A Revision of the Franklin Canon," American Literature 21.2 (1949): 151-159.

88. Breitwieser, Cotton Mather and Benjamin Franklin, 194.

89. Anthony Ashley Cooper, third earl of Shaftesbury, Characteristics of Men, Manners, Opinions, Times, Vol. 1, ed. Philip Ayers (Oxford: Clarendon Press, 1999), 194.

90. Shaftesbury, Characteristics of Men, 235.

91. Shaftesbury, Characteristics of Men, 199.

92. Shaftesbury, Characteristics of Men, 208.

93. Shaftesbury, Characteristics of Men, 272; 273.

94. Philip Ayres, "Introduction" to Anthony Ashley Cooper, third earl of Shaftesbury, Characteristics of Men, Manners, Opinions, Times, Vol. 1, ed. Philip Ayers (Oxford: Clarendon Press, 1999), xvii; Poovey, History of the Modern Fact, 177. On the parallel attempt 
by the Scottish Enlightenment thinker Frances Hutcheson to quantify good and evil actions see Poovey, Modern Fact, 29, 186; see also S. K. Aalto, "The Rise and Fall of Moral Algebra," Journal of the History of the Behavioral Sciences 17 (1981): 343-356.

95. James Don Edwards, "Early Bookkeeping and Its Development into Accounting,” Business History Review 34.4 (1960): 454. On Shaftesbury’s estate see Robert Voitle, The Third Earl of Shaftesbury, 1671-1713 (Baton Rouge: Louisiana State Univ. Press, 1984), 164-213.

96. Franklin's ivory notebook is lost but one owned by Thomas Jefferson survives. See Green and Stallybrass, Writer and Printer, 15.

97. Peter Stallybrass, "Benjamin Franklin: Printed Corrections and Erasable Writing," Proceedings of the American Philosophical Society 150.4 (2006): 561.

98. Houston, Benjamin Franklin and the Politics of Improvement, 36.

99. Stallybrass, "Printed Corrections and Erasable Writing," 567; Breitwieser, $\underline{\text { Cotton Mather }}$ and Benjamin Franklin, 284.

100. Stallybrass, "Printed Corrections and Erasable Writing," 567.

101. Stallybrass, "Printed Corrections and Erasable Writing," 567.

102. Muldrew, Economy of Obligation, 156.

103. Cheryl S. McWatters and Yannick Lemarchand, "Merchant Networks and Accounting Discourse: The Role of Accounting Transactions in Network Relations," Accounting History Review 23.1 (2013): 49. On Franklin's efforts to secure his creditworthiness and reputation see Houston, Benjamin Franklin and the Politics of Improvement, 47-49.

104. Thanks to James N. Green for drawing this episode to my attention.

105. This figure is based on the Consumer Price Index and was calculated at Measuring Worth.Com, https://www.measuringworth.com/ 
106. Richard Dienst, The Bonds of Debt: Borrowing Against the Common Good (London: Verso, 2011), 26. For a critique of the ways in which accounting enforces neoliberal forms of domination see Miranda Joseph, Debt to Society: Accounting for Life under Capitalism (Minneapolis: Univ. of Minnesota Press, 2014).

107. Georg Simmel, The Philosophy of Money, trans. Tom Bottomore and David Frisby (London: Routledge, 2006), 480. 